\title{
Upaya meningkatkan produktivitas anak-anak pada masa pandemi covid-19 melalui kegiatan positif di bagor kulon
}

\author{
Is Damayanti ${ }^{1}$, Nurul Dwi Lestari ${ }^{2}$ \\ ${ }^{1}$ Psikologi Islam, FUDA, Institut Agama Islam Negeri, Kediri \\ ${ }_{2}^{2}$ Dosen, Institut Agama Islam Negeri, Kediri \\ isdamayanti26@gmail.com
}

\begin{abstract}
During the covid-19 pandemic in Indonesian, the number of the people infected with the covid-19 virus is increasing. This has an impact on many aspects of everyone's life, whether in education, health, social, economic. In school children, learning is carried out boldly using mobile phones at home. This makes the mind saturated, the purpose of this community service is to eliminate boredom by increasing the productivity of children during the covid-19 pandemic through this positive service activity using the Participatory Action Research (PAR) method. In this community service activity, it is aimed at shool-age children in Bagor Kulon village. The application of various positive activities at school age children can make them more productive so that the mind is calmer and eliminates boredom. Activities that can be applied include fishing by reading and writing IQRA, learning to memorize letters, read a book, and small competitions including adhan competitions, poetry reading competitons, and short letter memorization competitions, and short letter memorization competitions. Activities are carried out with due observance of health protocols. As a result of community service through these positive activities, children have high enthusiasm to do positive activities and get positive benefits.
\end{abstract}

Keywords: productivity; implementation of positive activities; pandemic covid-19

\begin{abstract}
Abstrak
Masa pandemi covid-19 di Indonesia, saat ini penderita yang terinfeksi virus covid-19 meningkat. Hal ini berdampak pada banyak aspek dalam kehidupan setiap orang, baik dalam pendidikan, kesehatan, sosial, ekonomi. Pada anak-anak sekolah, pembelajaran dilaksanakan secara daring menggunakan handphone di rumah. Hal tersebut membuat pikiran menjadi jenuh. Tujuan dari pengabdian kepada masyarakat ini untuk menghilangkan rasa kejenuhan dengan meningkatkan produktivitas anak-anak pada masa pandemi covid19 melalui kegiatan positif. Metode pengabdian ini menggunakan metode Participatory Action Research (PAR). Dalam kegiatan pengabdian kepada masyarakat ini ditujukan kepada anak-anak usia sekolah di Desa Bagor Kulon. Penerapan berbagai kegiatan yang positif pada anak-anak usia sekolah dapat menjadikan mereka lebih produktif sehingga pikiran lebih tenang dan menghilangkan rasa kejenuhan. Kegiatan yang dapat diterapkan diantaranya : mengaji dengan membaca dan menulis iqra, belajar menghafal surat-surat pendek, membaca buku, dan perlombaan kecil meliputi lomba adzan, lomba membaca puisi, dan lomba menghafal surat-surat pendek. Kegiatan dilakukan dengan memperhatikan protokol kesehatan. Hasil dari pengabdian kepada masyarakat melalui kegiatan positif ini, anak-anak memiliki semangat yang tinggi untuk melakukan kegiatan positif dan mendapatkan manfaat yang positif.
\end{abstract}

Kata Kunci: produktivitas; penerapan kegiatan positif; pandemi covid-19

\section{PENDAHULUAN}

Indonesia adalah negara yang terjangkit virus covid-19. Virus covid-19 adalah salah satu virus yang menyebar di seluruh dunia. Penyebaran virus covid-19 ini membuat 
masyarakat melakukan pembatasan sosial untuk mencegah penyebaran virus covid-19. Pemerintah membatasi interaksi masyarakat dengan meminimalisir untuk keluar dari rumah yang di sebut sebagai social distancing.

Pada masa pandemi covid-19 saat ini, kegiatan pembelajaran sekolah dilakukan secara online melalui handphone. Berdasarkan observasi yang dilakukan di Desa Bagor Kulon, anak-anak usia sekolah melakukan aktifitas sehari-hari hanya dengan handphone dan bermain dengan permainan di handphone yang membuat mereka jenuh. Pengabdian ini dilakukan karena pada masa pandemi covid-19 dengan adanya kegiatan positif dapat meningkatkan produktivitas dalam kehidupan sehari-hari sehingga tidak menimbulkan kejenuhan dan menjaga kesehatan mental pada anak-anak.

Produktifitas adalah sebuah alat ukur dalam menilai prestasi kerja atau usaha yang dicapai seseorang. Menurut Dewan Produktifitas Nasional, produktifitas adalah sikap mental yang selalu berpandangan bahwa mutu kehidupan hari ini harus lebih baik dari hari kemarin, dan hari esok harus lebih baik dari hari ini. Produktivitas merupakan sikap yang senantiasa mempunyai pandangan bahwa hari ini lebih baik daripada hari kemarin, dan hasil esok hari harus lebih baik dari apa yang diraih hari ini. Poduktivitas adalah kegiatan yang menimbulkan atau meningkatkan kegunaan, meliputi kegunaan waktu, tempat, bentuk, dan kepemilikan. Gilmore menyatakan bahwa pribadi yang produktif ialah individu yang menghasilkan kontribusi bermanfaat bagi lingkungannya. Orang-orang produktif melakukan suatu pekerjaan menuju kebebasan positif dan realisasi berkesinambungan akan potensi mereka. Oleh karena itu, mereka merupakan karakter yang paling sehat di antara semuanya. Manusia yang sehat menilai suatu pekerjaan sebagai jalan untuk mengungkapkan diri secara kreatif.

Pandemi adalah epidemi penyakit yang menyebar di wilayah yang luas. Penyakit corona virus 2019 adalah penyakit yang menular disebabkan oleh sindrom pernapasan akut corona virus 2 (SARS0CoV-2). Pandemi covid-19 merupakan peristiwa menyebarnya penyakit virus corona di seluruh negara. Wabah penyakit virus corona ini pertama kali dideteksi di kota Wuhan, Hubei, Tiongkok. Pandemi covid-19 berdampak pada semua orang, sehingga tidak bisa bertemu langsung antara satu dengan yang lainnya. Kegiatan adalah aktivitas, usaha, atau pekerjaan. kegiatan merupakan perbuatan atau aktivitas yang dilakukan secara semangat supaya menjadi lebih giat. Kegiatan positif adalah suatu kegiatan yang jika dilakukan memiliki manfaat yang baik.

Pada jurnal Pengabdian Kepada Masyarakat (PKM) dengan judul "Mengembangkan kreativitas pada masa pandemi covid-19 melalui kegiatan positif di Rumah pintar AlIkhlas Jakarta Raya" yang ditulis oleh Dewi et al. (2021), mahasiswa manajemen Universitas Pamulang, hasil dari pengabdian kepada masyarakat yaitu : bertambahnya keterampilan dalam pembuatan tempat pensil serta bertambahnya kegiatan positif di masa pandemi pada siswa/i peserta didik di Rumah Pintar Al-Ikhlas Jakarta Raya dan meningkatnya keterampilan serta pengetahuan tentang kegiatan positif dengan cara memanfaatkan botol bekas. 
Pada jurnal Pengabdian Kepada Masyarakat (PKM) dengan judul "Upaya meningkatkan kreativitas dan produktivitas dengan penerapan manajemen waktu di masa pandemi covid-19" yang ditulis oleh Hanafi et al. (2021), mahasiswa manajemen Universitas Pamulang, hasil dari pengabdian kepada masyarakat yaitu : kegiatan upaya meningkatkan kreativitas dan produktivitas yang diterapkan berjalan dengan baik, dengan antusiasme adik-adik dalam kegiatan.

Keunggulan dari pengabdian kepada masyarakat melalui kegiatan positif di Bagor Kulon adalah kegiatan yang dilakukan lebih mengarah pada kegiatan keagamaan Islam sehingga anak-anak terbiasa melakukan kegiatan yang positif sejak dini. Berdasarkan uraian di atas, tujuan dari pengabdian kepada masyarakat yang dilakukan di Desa Bagor Kulon, Nganjuk adalah meningkatkan produktivitas anak-anak melalui kegiatan yang positif. Adapun tujuan khusus dari pengabdian kepada masyarakat ini mencakup (1) menghilangkan kejenuhan pada anak-anak di masa pandemi covid-19 (2) menjadikan kebiasaan yang baik sejak dini (3) melatih rasa percaya diri pada anak-anak.

\section{METODE PELAKSANAAN}

Metode pengabdian kepada masyarakat ini menggunakan metode Participatory Action Research (PAR), yaitu kegiatan riset yang dilakukan secara partisipatif di antara masyarakat dalam suatu komunitas atau lingkup sosial yang lebih luas untuk mendorong terjadinya aksi-aksi perubahan kondisi hidup yang lebih baik lagi. Teknik pengumpulan data yaitu dengan observasi dan angket berupa lembaran laporan kegiatan positif. Pelaksanaan pengabdian kepada masyarakat yaitu di Desa Bagor Kulon, Nganjuk. Waktu pelaksanaan pada tanggal 7 Juli sampai 13 Agustus 2021. Peserta pada pelaksanaan kegiatan yaitu 25 anak-anak Sekolah Dasar (SD) dan Sekolah Menengah Pertama (SMP).

Prosedur pelaksanaan pengabdian kepada masyarakat ini adalah pertama, kegiatan mengaji yang dilakukan adalah membaca dan menulis iqra, setiap 1 minggu sekali. Kedua, kegiatan sosialisasi hidup bersih dan disiplin. kegiatan ini dilakukan untuk memberikan pengetahuan kepada anak-anak usia dini tentang cara hidup bersih dan disiplin sejak dini agar mereka terbiasa. Mengingat saat ini dalam masa pandemi covid19, sehingga kegiatan sosialisasi ini perlu dilakukan untuk memberikan pemahaman kepada anak-anak tentang cara hidup bersih dengan cuci tangan yang benar, memakai masker ketika berada di luar rumah agar terhindar dari penyebaran virus covid-19. Ketiga, kegiatan positif yang dilakukan di rumah. Kegiatan ini dilakukan dengan mengajak anak-anak usia sekolah untuk melakukannya di rumah. Kegiatannya yaitu : merapikan tempat tidur, mencuci tangan dan kaki sebelum masuk rumah dan sebelum tidur, membuang sampah pada tempatnya. Anak-anak diberikan lembaran kegiatan yang akan dilakukan selama 16 hari mulai tanggal 17 Juli sampai 1 Agustus 2021, hasilnya dari kegiatan yang dilakukan ditulis dalam lembaran laporan. Keempat, membaca buku. Adanya perpustakaan mini bermanfaat untuk anak-anak usia agar 
mereka membaca buku. Buku-bukunya yaitu : buku pengetahuan, kitab, buku cerita, surat-surat pendek.

Kelima, perlombaan meliputi lomba adzan, lomba menghafal surat-surat pendek, lomba membaca puisi, lomba qiroatul kutub. Kegiatan ini dilakukan untuk meningatkan pemahaman anak-anak usia dini dalam keagamaan Islam, dan melatih rasa percaya diri.

\section{HASIL DAN PEMBAHASAN}

\subsection{Hasil}

Pelaksanaan kegiatan pengabdian kepada masyarakat ini dilakukan kepada anak-anak usia sekolah dengan melakukan kegiatan positif. Kegiatan dilakukan di masjid Nurul Jadid dan di rumah masing-masing partisipan.

Dari pelaksanaan kegiatan pengabdian kepada masyarakat dalam upaya meningkatkan produktivitas anak-anak pada masa pandemi covid-19 melalui kegiatan positif di Bagor Kulon mendapatkan hasil yang sangat baik. Pengabdian kepada masyarakat yang dilakukan di Desa Bagor Kulon ini, anak-anak usia sekolah sangat semangat dan senang untuk melakukan kegiatan yang positif. Hal ini ditandai dengan hasil angket laporan kegiatan positif yang terisi penuh. Sehingga ini menjadi kebiasaan yang baik sejak dini. Dalam pelaksanaan kegiatan di Masjid Nurul Jadid, mereka semangat mengikuti perlombaan, membaca buku, dan mengaji. Sehingga anak-anak usia sekolah tidak merasa jenuh dan percaya diri..

\subsection{Pembahasan}

Dari pelaksanaan kegiatan pengabdian kepada masyarakat yang di lakukan di Desa Bagor Kulon, berikut ini hasil dari lembaran angket laporan kegiatan positif yang dilakukan anak-anak sekolah dasar di rumah masing-masing selama 16 hari, mulai tanggal 17 Juli sampai 1 Agustus. Hasil dari laporan kegiatan 18 anak dari 25 anak, mereka melakukan kegiatan yang positif di rumah secara penuh dalam waktu 16 hari.

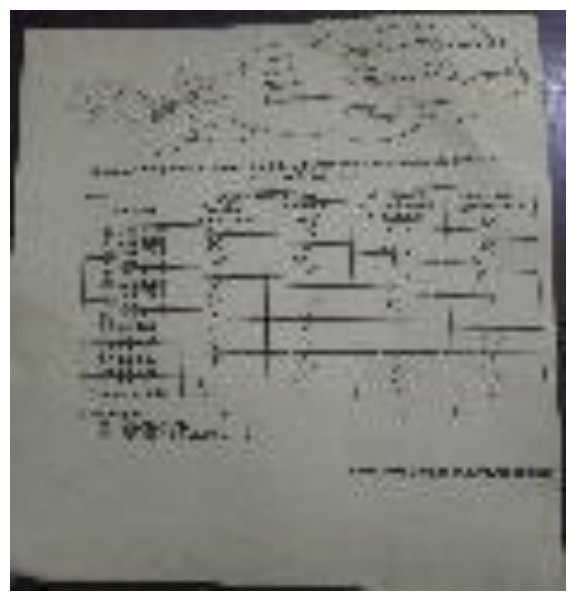

Gambar 1. Contoh hasil angket partisipan 
Tabel 1. Data Banyak Jumlah Kegiatan Positif yang Dilakukan

\begin{tabular}{|c|c|c|c|c|}
\hline \multirow[b]{2}{*}{ Nama } & \multicolumn{4}{|c|}{ Cuci tangan dan kaki } \\
\hline & Sebelum tidur & masuk rumah & $\begin{array}{l}\text { Buang sampah } \\
\text { pada tempatnya }\end{array}$ & $\begin{array}{l}\text { Merapikan } \\
\text { tempat tidur }\end{array}$ \\
\hline Lusi & 16 & 16 & 16 & 15 \\
\hline Davin & 15 & 15 & 16 & 14 \\
\hline Naya & 14 & 15 & 15 & 14 \\
\hline Danita & 13 & 9 & 13 & 7 \\
\hline Evi & 12 & 15 & 13 & 12 \\
\hline Clara & 16 & 16 & 16 & 16 \\
\hline Citra & 10 & 9 & 16 & 16 \\
\hline Shinta & 16 & 16 & 16 & 16 \\
\hline Eka & 16 & 16 & 16 & 16 \\
\hline Sucia & 15 & 15 & 16 & 16 \\
\hline Rifki & 16 & 16 & 16 & 16 \\
\hline Aditya & 16 & 16 & 16 & 16 \\
\hline Chika & 16 & 16 & 16 & 16 \\
\hline Windi & 15 & 10 & 16 & 12 \\
\hline Daffa & 16 & 16 & 16 & 16 \\
\hline Siska & 16 & 16 & 16 & 16 \\
\hline Yusuf & 16 & 16 & 16 & 16 \\
\hline Fais & 16 & 16 & 16 & 16 \\
\hline Madela & 16 & 16 & 16 & 16 \\
\hline Yogi & 16 & 16 & 16 & 16 \\
\hline Nu'ma & 16 & 16 & 16 & 16 \\
\hline Kenzo & 16 & 16 & 16 & 16 \\
\hline Jihan & 16 & 16 & 16 & 16 \\
\hline Vanesa & 16 & 16 & 16 & 16 \\
\hline Aldi & 16 & 16 & 16 & 16 \\
\hline
\end{tabular}

Keterangan : angka di setiap kolom adalah banyak kegiatan yang dilakukan selama 16 hari, mulai tanggal 17 Juli sampai 1 Agustus 2021

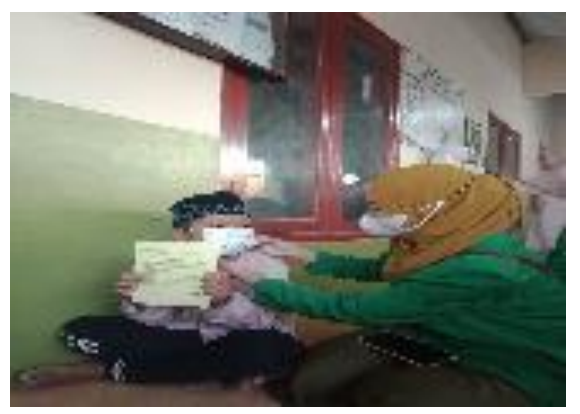

Gambar 2. Foto pembagian angket kegiatan positif

Selanjutnya dalam kegiatan mengaji yaitu membaca dan menulis iqra, mereka yang sebelumnya kurang hafal dengan huruf hijaiyah sehingga mereka kurang bersemangat menjadi ada peningkatan. Lebih semangat belajar, sehingga membaca secara lancar dan menulis lebih baik. 


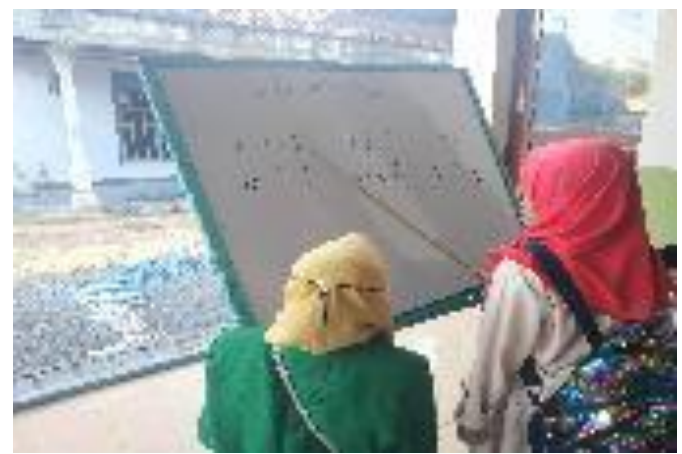

Gambar 3. Foto kegiatan mengaji

Kegiatan hafalan surat-surat pendek diajarkan sehingga anak-anak sekolah dasar hafal beberapa surat pendek yaitu Al- Fatihah, An-Naas, Al- Kautsar, Al- Ikhlas, Al-Falaq.

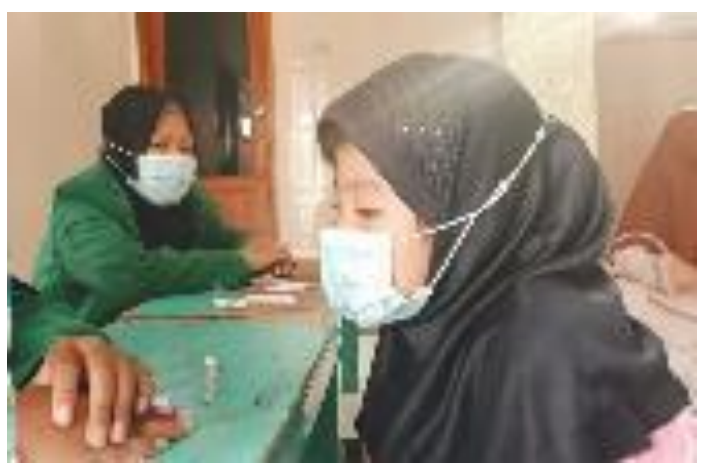

Gambar 4. Foto kegiatan hafalan surat-surat pendek

Dalam kegiatan pengabdian kepada masyarakat ini dibuat perpustakaan mini. Bukubuku yang ada di perpustakaan mini, yaitu : buku pengetahuan umum, kitab, buku cerita, dan surat-surat pendek. Adanya perpustakaan mini membuat anak-anak usia sekolah rajin membaca buku.

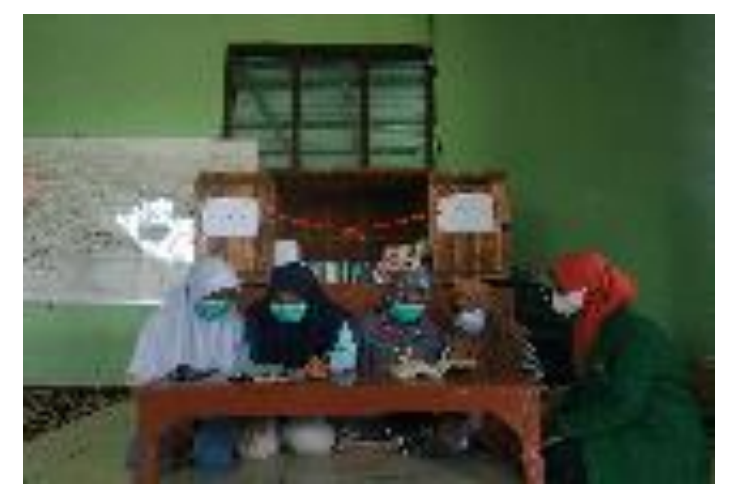

Gambar 5. Foto kegiatan membaca buku

Kegiatan perlombaan menjadikan rasa percaya diri anak-anak sekolah dasar meningkat, mereka semangat belajar dan tampil dengan baik. 


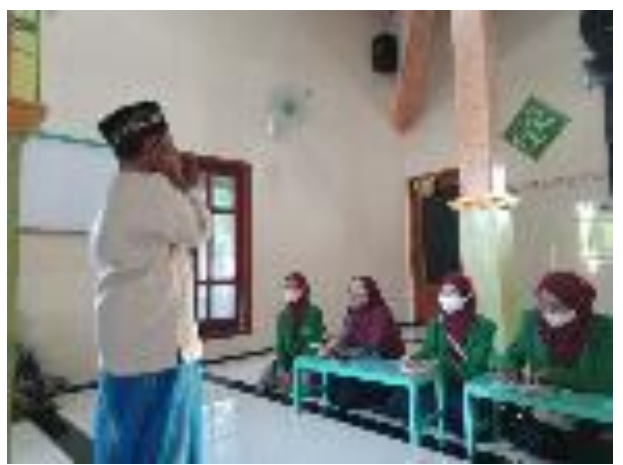

Gambar 6. Foto kegiatan perlombaan

\section{SIMPULAN}

Kegiatan pengabdian kepada masyarakat di Desa Bagor Kulon, dapat disimpulkan bahwa :

a. Anak-anak sekolah dasar menjadi lebih produktif dengan melakukan kegiatan yang positif yang dilakukan di rumah dan di masjid Nurul Jadid

b. Rasa percaya diri anak-anak sekolah dasar lebih bertambah dengan adanya perlombaan

c. Kemampuan anak-anak sekolah dasar dalam membaca dan menulis iqra meningkat

d. Kemampuan anak-anak sekolah dasar dalam menghafal surat-surat pendek bertambah.

e. Kejenuhan anak-anak sekolah dasar berkurang dengan melakukan kegiatan yang positif ini, mereka sangat bersemangat dalam melakukan kegiatan.

\section{REFERENSI}

Buchari, A. (2018). Kewirausahaan untuk mahasiswa dan umum. Bandung: Alfabeta.

Dewi, D., Kharisma, I., Akbar, F., Fadilah, N. N., Haliza, N., \& Atmadja, P. P. M. (2021). Mengembangkan kreativitas pada masa pandemi covid-19 melalui kegiatan positif di Rumah Pintar Al-Ikhlas Jakarta Raya. Jurnal Pengabdian Kepada Masyarakat (PKM): Kreasi Mahasiswa Manajemen, 1(2), 145-152.

Feist, J., Feist, G. J., \& Roberts, T. A. (2017). Teori kepribadian edisi kedelapan. Jakarta: Salemba Humanika.

Hanafi, M. I., Kharisma, I., Rizkia, A., Setiawati, S., Fathoni, S., \& Mariani, Y. (2021). Upaya meningkatkan kreativitas dan produktivitas dengan penerapan manajemen waktu di masa pandemi covid-19. Jurnal Pengabdian Kepada Masyarakat (PKM): Kreasi Mahasiswa Manajemen, 1(2), 130-136.

http://repository.uin-suska.ac.id. Diakses tanggal 12 Agustus 2021.

https://kbbi.web.id/kegiatan.html. Diakses tanggal 13 Agustus 2021.

Rambo Cronika Tampubolon. (2013). Participatory action research. https://www.bantuanhukum.or.idweb/participatory.action-research-par. Diakses tanggal 11 Agustus 2021. 
Siahaan, M. (2020). Dampak pandemi covid-19 terhadap dunia pendidikan. https://repository.ubharajaya.ac.id 2020. Diakses tanggal 10 Agustus 2021.

Soedjiwo, N. A. F. (2019). Implementasi mata kuliah PAR (PARTICIPATORY ACTION RESEARCH) di TPQ AL-MAGFIROH Denpasar Bali. Widya Balina, 4(8), 9-19.

Tamsil, H. A. (2021). Permasalahan penggunaan gadget pada tumbuh kembang anak usia dini di masa pandemi COVID-19. Jendela PLS, 6(1), 44-49. 